\title{
The Effectiveness of Exploration and Analysis on the Scientific and Technical Innovation of Universities of Science and Engineering to Improve the Art Education
}

\author{
Yuxin Hou \\ Architecture and Traffic Engineering College \\ Guilin University of Electronic Technology \\ Guilin, Guangxi, China, 541004
}

\begin{abstract}
Art education is an important way to stimulate students' enthusiasm for innovation and inspire innovative thinking. At the same time, scientific and technical innovation has a closely relation with art education. This paper analyzed the status quo of art education in universities of science and engineering and the relation between scientific and technical innovation and art education. To take the art education of developed countries put forward proposals for scientific and technical innovation to improve the art education.
\end{abstract}

Keywords - universities of science and engineering; innovation of scientific and technical; art education; effectiveness

\section{INTRODUCTION}

Art education, that is to put the art as a medium and content for education to impart art knowledge and artistic techniques and to nurture artistic spirit by joint activity of both educators and educated, is a educational activity to develop students' wisdom and continuously tap students' personal inner potential. With the deepen reform of higher education in China, colleges and universities focus on the cultivation of students' overall development in moral, intellectual, physical, aesthetic aspects. Art education, as an important component of quality-oriented education of higher education, so, if improving the effect of art education and integrating art education with innovation education effectively into colleges and universities, especially the task that is concern to universities of science and engineering.

\section{ThE FEATURES OF ART EDUCATION IN UNIVERSITIES OF SCIENCE AND ENGINEERING}

Students can sublimate ideology, affection, interest and charm and can develop a loving life and positive entrepreneurial spirit, and thereby form a sound cultural quality, psychological quality and innovative quality by art education. Our country has made art education as a important education for colleges and universities and issued a series of policies: the CPC Central Committee and State Council on intensifying education reform and promoting the qualityoriented education in an all-round way explicitly pointed out that colleges and universities should require students to take a certain period of humanities courses including art, and they should also carry out various cultural activities to strengthen students' aesthetic experience and to cultivate students' ability of appreciating and creating beauty. In1996, the Ministry of Education issued a circular on 'strengthening art education in general institutes of higher education' and made a clear claim on carrying out art education in general institutes of higher education, which promotes the development of art education and has a significant influence on promoting students' quality education. At the same time, education authorities as requested in 'the working rules for the arts education in schools' and 'the National School of arts education development plan (20012010)'actively carry out the examination and evaluation for art education and supervise and urge colleges and universities to pay attention to art education as requested.

Art education in universities of science and technology gradually started and showed its role of education in the improvement of art education in higher education in China. But art education in universities of science and engineering still has some features caused by discipline.

\section{A. In universities of science and engineering, teachers and students pay a little attention to art education}

For a long time, universities of science and engineering put more emphasis on passing on professional knowledge and skills, and even some teachers think that art education is a shock for professional study and that students taking art education as a kind of accommodation mode for life is a way of obtaining credits. They have an insufficient knowledge of art education, which leads to the ignorance to the humanistic knowledge and artistic culture and resulted in deficiency of aesthetic standards and disproportionality of IQ and EQ. In fact, science and art are two methods for human to understand world. Science is to understand world by abstract way of thinking while art is to understand world by imaginal way of thinking. Both can interpenetrate in the way of understanding world. Art provides inspiration for creating while science offers protection for the improvement of art. At present, our country attaches much importance on scientific and technical 
innovation in colleges and universities. Art education often can extend mind and inspiration for innovation.

\section{B. In universities of technology and engineering, teaching staff for art education is imperfect}

The traits of universities of science and engineering decided that teaching staff are dominated by professional teachers, art teachers are in shortage. According to the requirements of 'the working rules for the art education in schools and the National School of art education development plan (2001-2012)', the teaching staff for art education in nonart colleges and universities should be equipped by the $0.05 \%$ $0.1 \%$ of the number of students. , from the point of the whole nation, except a very few prestigious universities of science and engineering, almost all others falls far short of what is required. According to statistics, the task of art education in many colleges and universities relies on the school's Communist Youth League, especially the art education in campus cultural activities. Though it can be well-organized and carried out successfully, due to the acute shortage of teachers, it cannot have a comprehensive guide, which makes the second classroom can't play a full role in students'artistic experience and appreciation.

\section{There is a conflict between the course learning of students in universities of science and engineering and participation in artistic practice.}

Nowadays, with the rapid development of market economy, the competition is becoming fierce, which leads to the employment pressure of college graduates increasing. Especially for students of science and engineering, the pressure of course learning is relatively high for them and they have no more spare time to participate in artistic practice. So they can not enjoy the beauty and art that the artistic practice brings about. And then the conflict occurred, which directly affects the quality of artistic activities and results of art education. It also has an impact on developing students' interests in art. How to deal with the course learning and practice of art education becomes the focus for art education in colleges and universities.

\section{In universities of science and engineering, the hardware and software facilities for art education are inadequate.}

The management system and funding for art education in universities of science and engineering both are inadequate. The use of funding for art education in universities of science and engineering are often in the cart. For hardware facilities, the space for art education and artistic activities and modern equipment are imperfect. These problem are still existing in some universities of science and engineering, which hinders students from show interests in art learning and to enjoy artistic atmosphere. The guarantee for carrying out art education in colleges and universities is to strengthen the construction of hardware facilities and increase the fund and formulate effective incentive mechanism.

\section{ART EDUCATION AND SCIENTIFIC AND TECHNICAL} INNOVATION IN UNIVERSITIES OF SCIENCE AND ENGINEERING

'The application of art to science and technology, the application of science to art' is the trend of social development, is also a goal of higher education to nurture talents with creative qualities of thinking and culture and integrated development. Universities of science and engineering only analyze the close relation between innovation and art education can combine these two aspects well.

\section{A. Art education enriches scientific and technical innovation}

Art education is one of important sources for cultivating students' innovation ability. Art education is an appreciation that college students show for artistic beauty, natural beauty and social beauty and is also a process for them to know the nature, society and history. In this process, college students can not only accumulate knowledge but also stimulate the potential of innovation. Through imaging the experience and knowledge and with the action of emotion and thinking, students' innovative thinking is cultivated. Meanwhile, the lively arts activities with appreciation, performance and creation can tap into students' creativity, imagination and exhibitionism. It can show students' personality in actively participation and give a full play for creative thinking. Art education plays an important role in enhancing the creativity of students.

\section{B. Scientific and technical innovation promotes art education}

Innovation is the soul of a nation's progress and the unceasing power of a country's prosperity. Students of universities of science and technology are the main force for the scientific and technical development in our country. College students' creativity decides the scientific and technological innovation capacity of our country. On campus, the achievement of scientific and technical innovation constantly promotes the progress of colleges and universities including the enhancement of art education. Both idea of innovation and the adaption of achievement of innovation have a positive impact on the improvement of art education. The improvement of art education requires the constant introduction of idea of innovation to establish a mode fitting for the development of college students. What's more, the improvement of method and achievement of art education must take advantage of scientific and technical innovation. It needs the support of scientific and technical innovation for improving artistic presenting ability and art education reform.

\section{ForEIGN ART EDUCATION PROVIDES REFERENCE FOR CHINESE ARTS EDUCATION IMPROVEMENT}

\section{A. The revelation of American Art Education}

At present, more and more emphasis is put on art education in developed countries, which include it in the national education system. The United States is one of the countries which has a relatively perfect art education system, and as early as 1994, the US government adopted the "Target in 2000: American Education Act", which saw art education as one of the six key subjects of American elementary education in the form of act, improving the status of art education. The US government has promulgated the "National Standards of Art Education ", providing: Art is the core discipline of education, and art is inseparable from the meaning of the root word "education". It describes that "lack of basic knowledge and skills in art education can never be called a true education", 
"education without art is kind of incomplete education." Meanwhile, the "Standards" emphasizes the proper technique. Technique, in the proper use, can extend the art form and learner's perspective. New technique enables students to try a lot of new possibilities and ways to solve problems, the developing teaching techniques reveal an increasingly important role in the art teaching. Because technology is extending the range of choice, students must have a good guide when choosing and editing the teaching materials, and, so that can be a proper application of technology to achieve specific artistic goals. Clearly, the US government effectively combines art education with technical education.

\section{B. Russian Art Educational Implications}

Russia is a country with a long history and culture, creating a unique style of cultural art in the course of history and a valuable cultural asset for the world. Russia's culture education made important contribution to the cultural development. Russian art education has been regarded as an important social problem from the late 19th century to the present, it affects the nation's traditions, the future of the national and the spirit of the nation. Russian scholars believe that the task of art education should encourage children to love nature and life in order to arouse their creativity, and also hold that art education conducted in society, school and family can develop the capacity hidden of everyone. After that, Russia put forward the art education synergy system, including fostering innovation, promoting its leading position in the international art education. Of course, the theoretical art has laid a solid primary basis for art education in Russia, promoting coordinated development of teaching and education in art education activities, music; art and life are closely linked; human perception, appreciation and creative skills are brought up at the same time. In addition, the Board of Education of Russia also set up a research department of art education, which is responsible for art research, to enhance people's creativity and appreciation in the learning and labor process; making art education programs, proposing that teaching theory improves students' thinking skills and creativity. Russian coordinated training in art education, theory and education system are worthy of our study and reference.

\section{THE EFFECTIVENESS OF THE USE OF SCIENTIFIC AND TECHNOLOGICAL INNOVATION IN ART EDUCATION IN UNIVERSITIES OF SCIENCE AND ENGINEERING}

\section{A. Universities of science and engineering introduce innovative ideas in art education}

In recent years, our country continues to deepen education reform, change ideological education, and art education concepts also change, universities of science and engineering' art education should also conform to the education reform, according to its own characteristics, introducing innovative ideas. We should change the core idea of art education: to establish the concept of art education innovative ideas. Art promotes innovation, and so does the art education. It means not only changes in the content and methods, but also in educational theory and practice of art education to innovate, improving art education teaching, using theory to guide practice, but then perfect theory in the practice, encouraging teachers and students to explore the theory; in practice of innovation, based on the characteristics of art education in universities of science and engineering, we should explore a road of art education for a school situation with its own characteristics and the characteristics of students, so that students and teachers consensus on art education, putting importance of art education in the students' growth.

\section{B. Universities of science and engineering use innovative technology means in art education}

Colleges of science and engineering is the cradle of nurturing high-tech talent and future engineers, promoting technological innovation and cultivating batches of technological innovation talents, creating innovative selfdeveloped inventions implemented by large number of students. As an science and engineering college, art education should make full use of existing resources, it is the requirement of improving art education, on the other hand it can be effective in attracting students to participate in art education. For example, we should actively use network art education, art education software, and high-tech equipment, and also use a scoring system, laser energy saving lamps, video clips and other technological means in the student art activities, increasing the technological content of art education, improving the ornamental art education, fairness and technological nature, making it more fashionable. Thus, it will realize a good combination of student professional courses and art education, achieving win-win.

\section{Universities of science and engineering encourage the participation of talents of technological innovation in art education}

Art education in universities of science and engineering aims not to create art elite talents, but through the art education, we can enhance the aesthetic taste of college students, inherit a long tradition of cultural heritage, improve charisma and cultivate creative thinking ability. Art education of universities of science and engineering is not only to encourage students who have artistic talent or artistic professional to involve, while actively encouraging technological innovation talents participation, and improve their overall in art education. Albert Einstein once said: "Art makes me get more from the physical, imagination obtained from art is more important than knowledge, because knowledge is limited, whereas imagination summarize everything in the world, promoting the progress of the world, and is the source of knowledge evolution. "Art gives people an inexhaustible resource for innovation, finding inspiration and passion for science and technology in art education, the effect of art education will continue deep into students' consciousness.

\section{Universities of science and engineering integrate art education with innovative education}

Integrating art education with innovative education is the inevitable choice for universities of science and engineering. Innovative education is based on the principle of innovation, taking cultivate students' innovative spirits and practical ability as the basic value orientation for educational theories and methods. Through imposing educational impact on students, making them become independent, dynamic individuals, giving full play to their subjectivity, paying attention to new things, questioning, exploration, discovering new problems, acquiring new knowledge, exploring new ways to find new 
rules, thereby becoming an innovative quality talent with creative consciousness, creative personality, creative thinking, innovation etc. Art education is recognized as one of the most effective creative disciplines, and is a good way to train students' innovation and creativity. Colleges of Science and Engineering make art education resource and innovative education resource integration, playing both educational functions, realizing the training objectives that nurturing fulldeveloped talents with social competitiveness.

\section{REFERENCE}

[1] Luo Wei Qi, Art Education of College Students [J] CULTURE, 2007 (10)

[2] Wang Juan Juan, Lv Xin, American Art Education Thought [J], Chinese adult education, 2007 (11)

[3] Dong $\mathrm{Li} \mathrm{Li}$, Art education Problems in Polytechnic Colleges and Countermeasures [J], Shandong Electric Power College, 2006 (2)

[4] Qi Lin, Strengthen Art Education and Improve the Overall Quality of Science and Engineering Students [J], Anhui University of Technology (Social Sciences), 2006 (1),

[5] Huang Zuo Lin, Contemporary Art Education of Russia [J], Chongqing Normal University (Philosophy and Social Sciences), 2004 (05), p116120 